Saudi Journal of Business and Management Studies Abbreviated Key Title: Saudi J Bus Manag Stud ISSN 2415-6663 (Print) |ISSN 2415-6671 (Online) Scholars Middle East Publishers, Dubai, United Arab Emirates Journal homepage: https://saudijournals.com/sibms

Original Research Article

\title{
Simulation of Influence on Date of Sowing and Irrigation Levels on Grain Yield of Wheat using DSSAT-Model in Different Agroclimatic Zones of Uttar Pradesh, India
}

\author{
A. K. Baxla ${ }^{1 *}$, R. K. Mall ${ }^{2}$, K. K. Singh ${ }^{1}$, P. K. Singh ${ }^{3}$, G. B. Gohain ${ }^{4}$, Lata Vishnoi ${ }^{1}$ \\ ${ }^{1}$ India Meteorological Department, New Delhi, India \\ ${ }^{2}$ Banaras Hindu University, Ajagara, Varanasi, Uttar Pradesh 221005, India \\ ${ }^{3}$ Centre for Disaster Management, LBSNAA, Mussoorie \\ ${ }^{4}$ Munich Re India, BKC, Mumbai, India
}

\begin{abstract}
DOI: $10.36348 /$ sjbms.2020.v05i05.002
| Received: 19.05.2020 | Accepted: 27.05.2020 | Published: 30.05.2020
\end{abstract}

*Corresponding author: A. K. Baxla

\section{Abstract}

The CERES Wheat (V4.6) Simulation Model was calibrated and validated using experimental field data collected on phenology, yield and yield attributes of ruling cultivars of wheat under FASAL (Forecasting Agricultural output using Space, Agro meteorology and Land base observation) scheme during the winter (rabi) seasons of 2012-13 to 2015-16 at Faizabad, Modipuram, Kanpur, Allahabad and Varanasi AMFUs (Agrometeorological Field Units) of Uttar Pradesh under irrigated condition with the objective to study the growth and yield of wheat at different sowing dates and irrigation levels and to simulate trends of wheat production. The genetic coefficient derived from the calibration of the CERES-Wheat Model for both varieties PBW-343 and Malviya-234 were reasonably very close to observed yield. Therefore, the model as used for evaluation of sowing date and irrigation level in wheat crop. The model was run for six sowing dates on seven days interval i.e.30 October, 06, 13, 22 \& 27 November and 5 December and increasing level of (five) irrigations. Simulation studies depicts that the model performance was good under three $\left(\mathrm{I}_{3}\right)$ and four $\left(\mathrm{I}_{4}\right)$ irrigation level , after five $\left(I_{5}\right)$ irrigation yields are same as $I_{4}$ in most of the districts of different agro climatic zone while poor performance was observed under two $\left(\mathrm{I}_{2}\right)$ and one $\left(\mathrm{I}_{1}\right)$ irrigation level. Wheat yield was also simulated at different sowing dates, results shows that 22 November is the optimum sowing date for Bundelkhand, Central Plain, Eastern Plain, NE Plain and Vindhyan zone and 13 November for Mid western Plain, SW Plain, Bhabhara \& Tarai and Western plain zone while less yield was observed in early and late sowing.

Keywords: Weather data, Soil data, Genetic coefficient and Irrigation.

Copyright @ 2020: This is an open-access article distributed under the terms of the Creative Commons Attribution license which permits unrestricted use, distribution, and reproduction in any medium for non-commercial use (NonCommercial, or CC-BY-NC) provided the original author and source are credited.

\section{INTRODUCTION}

Wheat (Triticum aestivum L.) is one of the important staple foods in India and is grown under diverse sets of agro-climatic conditions. In the country, it is grown in the region within latitudes $15^{\circ}$ to $32^{0} \mathrm{~N}$ and longitudes $72^{\circ}$ to $92^{\circ} \mathrm{E}$ under irrigated conditions. Punjab, Haryana, Uttar Pradesh, Uttarakhand, Madhya Pradesh, Rajasthan and Bihar are the leading states of India contributing more than 90 percent of the wheat for the country. In India, wheat is next to paddy in area and production, grown over an area of 27.75 million hectares with an annual production of 80.68 million tones. India rank second after China in wheat growing countries. It is considered to be the backbone of the food security in India. Wheat is sown during November to December and harvest during March to April. The wheat-marketing season in India is assumed to begin from April every year.

Weather variables are one of the key components, which influence on growth, development and yield of the wheat crop over which man has very little control. Increased climatic variabilities and aberrant variations in meteorological parameters like hailstorm, frost, high wind and extreme temperature and 
foggy condition during wheat growing (Rabi) season leads to natural disasters affecting wheat productivity, over the past few years, per hectare yield of wheat in India has fallen due the temperature rising steadily in January, February and March, a time most crucial for the wheat crop [1-3]. During January and February of 2006 temperatures kept rising steadily due to prolonged absence of rain. Since wheat is sensitive to moisture stress, it needs frequent irrigation for good growth and yield [4]. The average day and night temperatures have been $4-6^{0} \mathrm{C}$ higher than the normal, most striking during February, in wheat sowing region of the country, with the raised temperatures, crop matures early. The response to temperature varies with the stage of development, mainly booting (late ear development), anthesis (pollination and fertilization) and grain growth (a week after anthesis to maturity [5]. Wheat productivity can be increased substantially by adjusting sowing date to optimum atmosphere temperature which encounters critical phenological stages of wheat. CERES-wheat crop simulation model has been widely tested and validated under diverse agro-climatic conditions in different states of India for various uses such as predicting growth stage and crop duration, grain yield simulation, effect of planting dates on crop and water requirement, irrigation scheduling, nitrogen management [6]. Now several crop simulation models available which enable to assess the impact of different meteorological parameters on crop growth and yield [79]. The present study is aimed at the evaluation of CERES (Crop Environment Resource Synthesis) Wheat model for optimum sowing date and irrigation scheduling on wheat crop.

\section{DATA AND METHODOLOGY}

The field experiment was conducted during the winter (rabi) seasons of 2012-13 to 2015-16 under FASAL (Forecasting Agricultural output using Space, Agrometeorology and Land base observation) scheme at the experimental farm of (i) Narendra Deva Univerity of Agriculture \& Technology, Faizabad, (ii) Sardar Vallabhbhai Patel University of Agriculture, Modipuram, Merrut (iii) Chandra Shekhar Azad University of Agriculture \& Technology, Kanpur (iv) Sam Higginbottom University of Agriculture, Technology \& Sciences, Allahabad and (v) Institute of Agricultural Sciences, BHU, Varanasi. The data were collected on phenology, yield and yield attributes of ruling cultivars of wheat for calibration and validation. In this study two ruling cultivars PBW-343 and Malviya -234 were used under irrigated conditions for all districts of different agroclimatic zones of Uttar Pradesh, with the objective to study the growth and yield of wheat at different sowing dates and irrigation levels and to simulate trends of wheat production.

\section{Study Site}

The study primarily focused on the districts falls under different agroclimatic zones of Uttar Pradesh where wheat is extensively cultivated, about nine agroclimatic wheat growing zones viz; Vindhyan Zone, North Eastern Plain Zone, Bundelkhand Zone, Central Plain Zone, Western Plain Zone, South Western Semi Arid Zone, Eastern Plain zone, Bhabhra and Tarai Zone and Mid Western Plain Zone taken for study (Table-1).

\section{Data Collection}

District wise wheat yield data for past ten years collected from State Department of Agriculture, Government of Uttar Pradesh and Ministry of Agriculture \& Farmers' Welfare, Government of India, New Delhi.

\section{Meteorological data}

The long term historical daily weather data (2002-2012) at district level were collected from National Data Centre, IMD-Pune, Meteorological Centre, Lucknow and Agromet Field Units (AMFUs) of Uttar Pradesh for the variables;

- Maximum Temperature $\left({ }^{\circ} \mathrm{C}\right)$

- $\quad$ Minimum Temperature $\left({ }^{\circ} \mathrm{C}\right)$

- Rainfall (mm)

- Bright Sun Shine (Hours) /Solar Radiation $\left(\mathrm{MJm}^{-2}\right)$ (but some districts are not available)

The main function of the weather module is to read or generate daily weather data. It reads in daily weather values (maximum and minimum air temperature, solar radiation and precipitation) from the daily weather file. Hourly weather values are computed for use by the modules which require them. Solar radiation is derived from sunshine hour's data using Angstrom method [10]. This module generates daily weather data using the WGEN $[11,12]$ or SIMMETEO23, 24 weather generators. In-season time series of daily weather data at district level is received from Meteorological Centres of IMD and AMFUs.

\section{Crop experiment data and Minimum data sets}

The crop and soil related information was taken from Agromet Field Units (AMFUs) for running the model Minimum data sets required are collected from AMFUs of IMD.

\section{Crop Attributes}

Sowing date, Anthesis date, Physiological maturity date, Grain yield at maturity $\left(\mathrm{kg} \mathrm{ha}^{-1}\right)$, weight of grains (mg/unit), No. of grains $/ \mathrm{m}^{2}$, No. of grains/ spike, Maximum Leaf Area Index, Tops weight at maturity $\mathrm{kg} \mathrm{ha}^{-1}$, Bi-product harvest- $\mathrm{kg} \mathrm{ha}^{-1}$, Grain $\mathrm{N}$ at maturity \%, Tops $\mathrm{N}$ at maturity $\mathrm{kg} \mathrm{ha}^{-1}$, Stem at maturity $\mathrm{kg} \mathrm{ha}^{-1}$, Grain $\mathrm{N}$ at maturity $\mathrm{kg} \mathrm{ha}^{-1}$.

\section{Management aspects considered in the study}

Planting depth, Row spacing \& Plant population at seeding, Plant method \& distribution, Fertilizer $120 \mathrm{~kg}$ Nitrogen applied half as basal dose and rest in two splits, Irrigation schedule in Table 2. Two cultivars PBW-343 and Malviya - 234 were selected for the study. The model was run for six 
sowing dates on seven days interval i.e.30 October, 06, $13,22 \& 27$ November and 5 December and increasing level of (five) irrigations.

\section{Soil Parameters}

Soil inputs include physical and chemical description of the soil profile with separate information for each horizon, soil reflection coefficient, soil water drainage constant, USDA SCS runoff curve number, thickness of soil layer, permanent wilting point, field capacity, saturated water content, bulk density $\left(\mathrm{gm} / \mathrm{cm}^{3}\right)$, organic carbon content $(\%), \mathrm{pH}$ for each layer of the soil profile, root distribution weighing factor in different layers and initial soil water soil water content for the different soil layers.

\section{Genetic Coefficients}

Crop genetic input data, which explains how the wheat cultivar during its life cycle responds to the environment, has been developed for different cultivars PBW-343, Malviya-234 [1].

\section{RESULT AND DISCUSSION Different Sowing Date}

CERES-wheat model (DSSAT v 4.6-Decision Support System for Agrotechnology Transfer) was calibrated for wheat (PBW-343 and Malviya-234) at different Agroclimatic zones of using data collected under different management practices (Date of sowing $\mathrm{x}$ Irrigation) during 2002-2012. The model was run for 6 sowing dates starting on 30 October and repeated every 7 days until 5 December using long-term district level station and gridded level historical weather data from different district. In Bundelkhand agroclimatic zone (ACZ) highest mean yield 4173 to $5186 \mathrm{kgha}^{-1}$ in 22 and 27 November sowing date respectively and lowest $2560 \mathrm{~kg} \mathrm{ha}^{-1}$ in 30 October early sown date in all districts of Bundelkhand ACZ. The simulation yield was over simulated from observed yield from districts at par with the districts in Bundelkhand ACZ (Table-3, Fig-1 \& Map 1). The range of RMSE value was 1330 to $2540 \mathrm{kgha}^{-1}$ (Table-3). The goodness of fit was not significant except Lalitpur and Jalaun districts. Simulated yield was ranged between 2436.0 to 4338.7 $\mathrm{kg} \mathrm{ha}^{-1}$ for Central plain zone. The RMSE value was ranged 522 to $1526 \mathrm{~kg} \mathrm{ha}^{-1}$ and goodness of fit is nonsignificant in almost all districts. In this agroclimatic zone the sowing dates of $22 \mathrm{Nov}$ was sowing higher yields, while lower yield are seen in 30 October sowing date in all districts of central plain ACZ (Table-3, Fig-1 \& Map 1). Simulated yield was ranged between 2491.7 to $4135.5 \mathrm{~kg} \mathrm{ha}^{-1}$ for Eastern plain zone. The RMSE value was ranged 506.3 to $1570.4 \mathrm{~kg} \mathrm{ha}^{-1}$ and goodness of fit is non-significant in almost all districts. In this agroclimatic zone the sowing dates of 22 Nov was sowing higher yields, while lower yield are seen in 30 October sowing date in all districts of eastern plain ACZ. In Mid Western Plain agroclimatic zone highest mean yield is 4254.3 to $4231.9 \mathrm{~kg} \mathrm{ha}^{-1}$ on 6 and 13 November sowing date respectively and lowest 3539.1 $\mathrm{kg} \mathrm{ha}^{-1}$ in 5 December late sown dates in all districts expect Barelley, Badaun and Moradabad where 30 October sowing dates shows lower yield (Table-3, Fig-1 \& Map 1). SD was ranged 254.2 to $500.0 \mathrm{~kg} \mathrm{ha}^{-1}$ and $\mathrm{CV}$ ranged 5.9 to 16.2 percent of the different sowing date. The RMSE was ranged 370.6 to $1271.6 \mathrm{~kg} \mathrm{ha}^{-1}$ and this goodness of fit is not significant. The district yield was under estimated as per with simulated yield. The early (30 October) and late sowing (5 December) dates shows less yield, but normal sown date having higher yield. The higher yield shows on 22 Nov except Sharbatinagar, Gonda and Baharich district (Table-3, Fig-1 \& Map-1). The RMSE value ranged 343.3 to 1927.2 at these districts and was not significant. All districts in South Western Plain zone shows higher yield on 13 November sowing date and lower yield shows on early date of sowing. 13 November should be considered as normal sowing date in all districts of south western plain zone. The range of RMSE value was 812 to $1068 \mathrm{~kg} \mathrm{ha}^{-1}$. The maximum yield depicts on 22 November except Mirzapur district in Vindhyan zone and lower yield shows on early date of sowing. The RMSE value ranges 1277.3 to $1714.9 \mathrm{~kg} \mathrm{ha}^{-1}$ and only one was significant of Sonebhadra district. The RMSE value showed higher than the districts yield was under estimate from simulate district yields. The early sown date (30 October) shows lower yield in all districts of western plain zone and shows higher yield on 13 November sowing date except Bagpat and Bulandsahar districts. The RMSE value ranged 248.4 to $783.2 \mathrm{~kg} \mathrm{ha}^{-1}$ at these districts and was not significant (Table-3). In Bhabhara \& Tarai zone; the highest yield was $4538.7 \mathrm{~kg} \mathrm{ha}^{-1}$ on $6 \mathrm{Nov}$ in Sarbatinagr and the lowest yield was $3361.6 \mathrm{~kg} \mathrm{ha}^{-1}$ on 5 Dec in Saharanpur district (Table-3, Fig-1 \& Map-1). The range of RMSE was $354 \mathrm{~kg} \mathrm{ha}^{-1}$ in Saharanpur to $2174 \mathrm{~kg} \mathrm{ha}^{-1}$ in Sarbatinagar district. The SD and CV was $333.2 \mathrm{~kg} \mathrm{ha}^{-1}$ and 9.0 percent in same of all sowing dates in Bhabhara $\&$ Tarai zone (Table-3). The simulated yield was over estimated from district yield for sowing date all agroclimatic zones except western plain zone in Uttar Pradesh but simulated yield was underestimated from district yield for sowing dates (Fig-1).

\section{Different Irrigation}

In Bundelkhand agroclimatic zone the highest yield $4592.3 \mathrm{~kg} \mathrm{ha}^{-1}$ was on $\mathrm{I}_{4}$ except Hamirpur district where highest yield $4110.5 \mathrm{~kg} \mathrm{ha}^{-1}$ was on $\mathrm{I}_{3}$ irrigation, after fourth irrigation no variation of the yield has been seen in the districts of Bundelkhand ACZ on 22 and 27 November sowing date. The SD \& CV was ranged between 200.4 to $525.6 \mathrm{~kg} \mathrm{ha}^{-1}$ and 4.8 to 23.7 percent. The RMSE value ranges 1511.0 to $2396.4 \mathrm{~kg} \mathrm{ha}^{-1}$. The simulated yield ranged between 2185.5 to $3724.3 \mathrm{~kg}$ ha ${ }^{1}$ on 30 October and lowest yield seen on the $\mathrm{I}_{2}$. The SD \& CV was ranged between 309.9 to $495.7 \mathrm{~kg} \mathrm{ha}^{-1}$ and 12.2 to 17.5 percent. The RMSE value ranges 678.07 to $1462.4 \mathrm{~kg} \mathrm{ha}^{-1}$. Overall result showed the high yield was at normal sowing with three irrigations, but late sowing is more with five irrigations but yield compare to 
normal sowing date is less. In central plain zone, the simulated yield ranged between 1270.3 to $3962.4 \mathrm{~kg}^{-}$ ${ }^{1}$ on 30 October and highest yield seen on $\mathrm{I}_{2}$ and $\mathrm{I}_{3}$ irrigation. The SD \& CV was ranged between 127.2 to $643.2 \mathrm{kgha}^{-1}$ and 5.4 to 14.4 percent. The RMSE value ranges 101.0 to $889.7 \mathrm{~kg} \mathrm{ha}^{-1}$. In Eastern Plain Zone, the simulated yield ranged between 1694.7 to $3846.8 \mathrm{kgha}^{-1}$ on 30 October and lowest yield seen on $\mathrm{I}_{2}$ and $\mathrm{I}_{3}$ irrigation. The SD \& CV was ranged between 151.7 to $339.3 \mathrm{~kg} \mathrm{ha}^{-1}$ and 7.2 to 14.2 percent. The RMSE value ranges 72.3 to $521.7 \mathrm{~kg} \mathrm{ha}^{-1}$ (Table 3 \& Fig.2). In Eastern plain agroclimatic zone the highest yield 3957.0 $\mathrm{kg}$ ha-1was on $\mathrm{I}_{3}$ after third irrigation no variation of the yield has been seen in the districts of Eastern plain ACZ on 22 November sowing date. The SD \& CV was ranged between 221.9 to $854.6 \mathrm{~kg} \mathrm{ha}^{-1}$ and 4.8 to 47.3 percent. The RMSE value ranges 24.3 to $1004.1 \mathrm{~kg} \mathrm{ha}^{-1}$. In Mid western plain zone the highest yield ranges from 3554.7 to $4453.4 \mathrm{~kg} \mathrm{ha}^{-1}$ on 6 and 13 November and highest yield seen on $\mathrm{I}_{3}$ and $\mathrm{I}_{4}$ irrigation. The SD \& CV was ranged between 179.2 to $1066.5 \mathrm{~kg} \mathrm{ha}^{-1}$ and 3.9 to 39.5 percent. The RMSE value ranges 91.8 to $1049.9 \mathrm{~kg}$ $\mathrm{ha}^{-1}$. Under late condition, the simulated yield ranged between $1694.7 \mathrm{~kg} \mathrm{ha}^{-1}$ to $3846.8 \mathrm{~kg} \mathrm{ha}^{-1}$ on 5 December and lower yield seen on $\mathrm{I}_{4}$ irrigation (Table-3 \& Fig-2). The SD \& CV was ranged between 239.5 to $979.1 \mathrm{~kg}$ ha- 1 and 7.1 to 42.1 percent. The RMSE value ranges 16.2 to $489.9 \mathrm{~kg} \mathrm{ha}^{-1}$. In North Eastern Plain zone the highest yield ranges from $3128.6 \mathrm{~kg} \mathrm{ha}^{-1}$ to $4457.5 \mathrm{~kg}$ ha $^{-1}$ on 22 November and highest yield seen on $\mathrm{I}_{3}$ irrigation (Fig-2). The SD \& CV was ranged between 240.8 to $854.6 \mathrm{~kg} \mathrm{ha}^{-1}$ and 3.4 to 47.3 percent. The RMSE value ranges 24.3 to $1259.2 \mathrm{~kg} \mathrm{ha}^{-1}$. Under early sown condition yield at $\mathrm{I}_{3}$ irrigation is maximum on 30 October while under late sown condition 5 December yield is maximum on $\mathrm{I}_{4}$ irrigation (Table-3). In North Eastern Plain zone the highest yield ranges from 4341.5 $\mathrm{kg}$ ha-1to $4479.0 \mathrm{~kg} \mathrm{ha}^{-1}$ on 13 November and high yield seen in $\mathrm{I}_{5}$ in most of the districts of SW plain zone. The SD \& CV was ranged between 246.8 to $755.0 \mathrm{~kg}$ $\mathrm{ha}^{-1}$ and 5.7 to 33.3 percent. The RMSE value ranges 558.3 to $829.4 \mathrm{~kg} \mathrm{ha}^{-1}$. Under early sown condition the highest yield ranges from $3690.7 \mathrm{~kg} \mathrm{ha}^{-1}$ to $3961.0 \mathrm{kgha}^{-}$ ${ }^{1}$ on 30 October and highest yield seen on $\mathrm{I}_{3}$ irrigation (Table-3 \& Fig-2). The SD \& CV was ranged between 208.3 to $554.2 \mathrm{~kg} \mathrm{ha}^{-1}$ and 8.7 to 18.4 percent. The RMSE value ranges 156.9 to $492.9 \mathrm{~kg} \mathrm{ha}^{-1}$. In Vindhyan zone overall the result showed that maximum three irrigation needed for all different date of sowing. The maximum yield was normal sowing date and early and late sown yield was less than the normal sowing date. The highest yield ranges from $3852.0 \mathrm{~kg} \mathrm{ha}^{-1}$ to 3971.9 $\mathrm{kg} \mathrm{ha}^{-1}$ on 22 November and high yield seen in $\mathrm{I}_{3}$ in most of the districts of Vindhyan zone. The SD \& CV was ranged between 193.6 to $468.2 \mathrm{~kg} \mathrm{ha}^{-1}$ and 5.4 to 28.7 percent. The RMSE value ranges 462.8 to 1321.9 $\mathrm{kg} \mathrm{ha}^{-1}$. Under early sown condition the highest yield ranges from $2442.0 \mathrm{~kg} \mathrm{ha}^{-1}$ to $3206.5 \mathrm{~kg} \mathrm{ha}^{-1}$ on 30 October and highest yield seen on $\mathrm{I}_{2}$ irrigation. The SD \& CV was ranged between 244.2 to $471.0 \mathrm{~kg} \mathrm{ha}^{-1}$ and 11.6 to 16.6 percent. The RMSE value ranges 462.8 to $1321.9 \mathrm{~kg} \mathrm{ha}^{-1}$. In Western Plain zone the highest yield ranges from $3579.0 \mathrm{~kg} \mathrm{ha}^{-1}$ to $3914.0 \mathrm{~kg} \mathrm{ha}^{-1}$ on 13 November and high yield seen in $\mathrm{I}_{3}$ in most of the districts of Western plain zone. The SD \& CV was ranged between 216.2 to $786.6 \mathrm{~kg} \mathrm{ha}^{-1}$ and 6.3 to 35.1 percent. The RMSE value ranges 60.8 to $518.4 \mathrm{~kg} \mathrm{ha}^{-1}$. Under early sown condition the highest yield ranges from $2496.1 \mathrm{~kg} \mathrm{ha}^{-1}$ to $3375.5 \mathrm{~kg} \mathrm{ha}^{-1}$ on 30 October and highest yield seen on $\mathrm{I}_{2} \& \mathrm{I}_{3}$ irrigation (Fig-2). The SD \& CV was ranged between 247.8 to $415.7 \mathrm{~kg} \mathrm{ha}^{-1}$ and 7.4 to 17 percent. The RMSE value ranges 200.3 to $1395.4 \mathrm{~kg} \mathrm{ha}^{-1}$. The highest yield was $3958.5 \mathrm{~kg} \mathrm{ha}^{-1}$ in 13 Nov but the lowest yield was $3581.6 \mathrm{~kg} \mathrm{ha}^{-1}$ on 05 Dec on Bhabhara \& Tarai zone. The mean yield was $3813 \mathrm{~kg} \mathrm{ha}^{-1}$ and SD was $141.2 \mathrm{~kg} \mathrm{ha}^{-1}$ and also CV was 3.7 percent (Table-3). The highest yield was $\mathrm{I}_{4}(4148 \mathrm{~kg}$ $\left.\mathrm{ha}^{-1}\right)$ as followed $\mathrm{I}_{3}\left(4119 \mathrm{~kg} \mathrm{ha}^{-1}\right)$ in Bhabhara \& Tarai zone in Uttar Pradesh (Fig-2). In Irrigation conditions, normalized RMSE were $520.7 \mathrm{~kg} \mathrm{ha}^{-1}, 549.9 \mathrm{~kg} \mathrm{ha}^{-1}$, $564.8 \mathrm{~kg} \mathrm{ha}^{-1}, 693.6 \mathrm{~kg} \mathrm{ha}^{-1}, 748.4 \mathrm{~kg} \mathrm{ha}^{-1}, 831.3 \mathrm{~kg}$ ha ${ }^{1}, 894.6 \mathrm{~kg} \mathrm{ha}^{-1}, 1514.0 .3 \mathrm{~kg} \mathrm{ha}^{-1}$ and $1687.9 \mathrm{~kg} \mathrm{ha}^{-1}$ for SW plain zone, Western plain zone, Mid western plain zone, Central plain zone, NE plain zone, Eastern plain zone, Bhabhara \& Tarai zone, Vindhyan zone, and Bundelkhand zone respectively (Table-3). Optimum sowing window was different among districts. Simulation results depicts that 22 November is the optimum sowing date for Bundelkhand, Central Plain zone, Eastern plain zone, NE Plain zone and Vindhyan zone and 13 November for Mid western plain zone, SW plain zone, Bhabhara \& Tarai zone and Western plain zone.

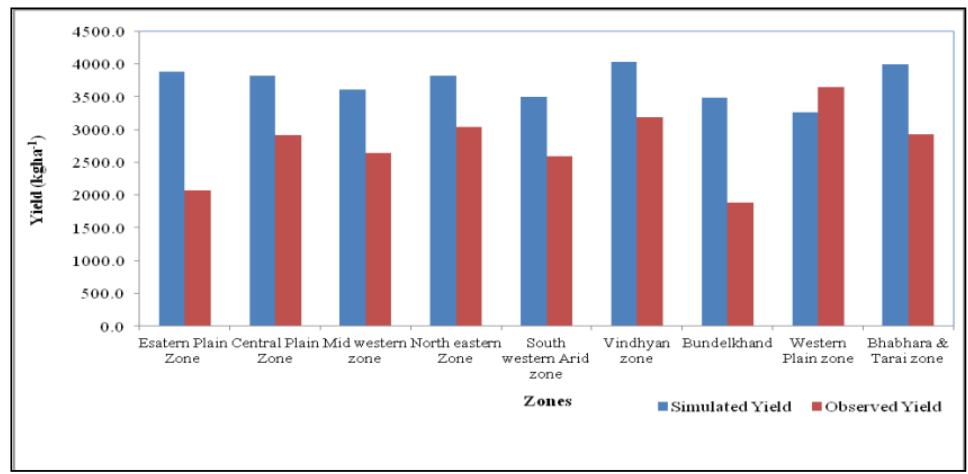

Fig-1: Mean of yield $\left(\mathrm{kg} \mathrm{ha}^{-1}\right)$ of different sowing dates of wheat crop of different agroclimatic zones 


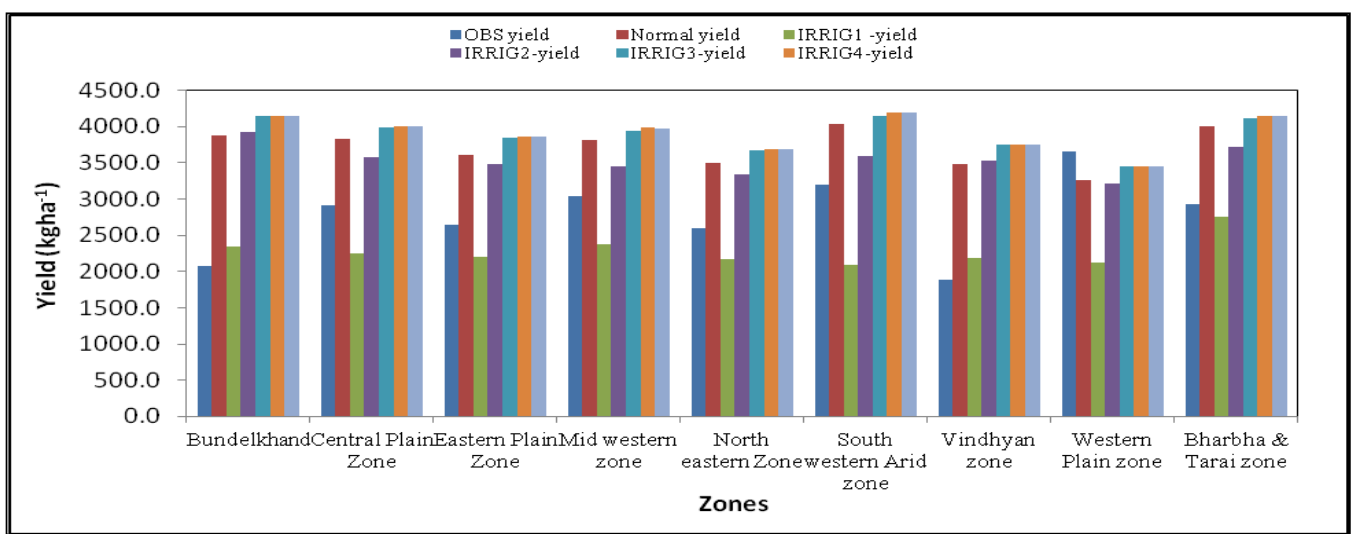

Fig-2: Mean of yield $\left(\mathrm{kg} \mathrm{ha}^{-1}\right)$ of different Irrigation of wheat crop of different agroclimatic zones
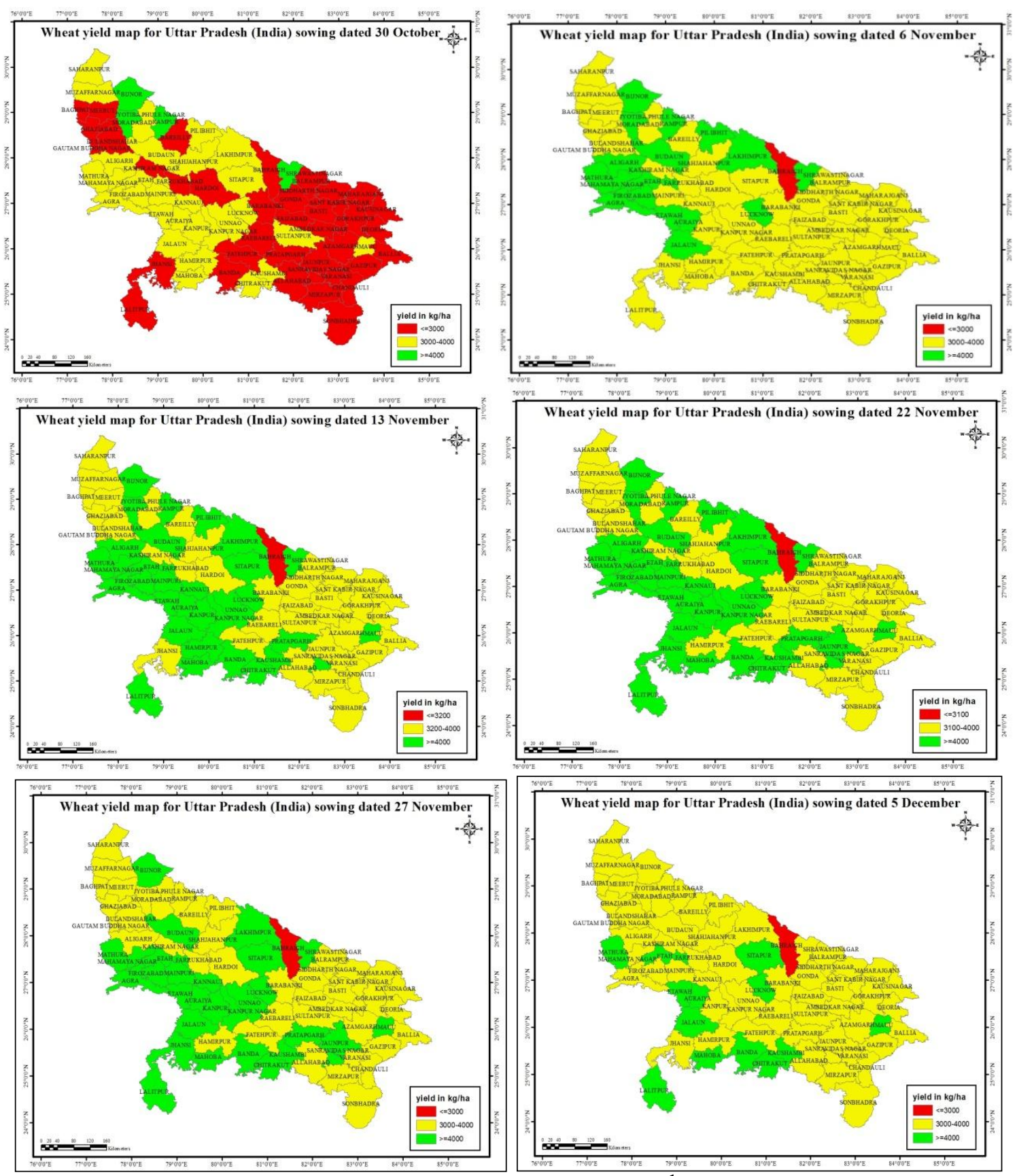

Map-1: Evaluation of DSSAT-CERES model for yield $\left(\mathrm{kg} \mathrm{ha}^{-1}\right)$ of different sowing date 
Table-1: Districts under different Agroclimatic zones of Uttar Pradesh

\begin{tabular}{|c|c|c|}
\hline $\begin{array}{l}\text { Sl. } \\
\text { no }\end{array}$ & $\begin{array}{l}\text { Agroclimatic } \\
\text { Zones }\end{array}$ & Districts \\
\hline 1. & Bundelkhand Zone & Banda, Lalitpur, Mahoba, Chitrahut, Hamirpur, Jalaun, Jhansi \\
\hline 2. & Central Plain Zone & $\begin{array}{l}\text { Auraiya, Etawah, Farrukabad, Fatehpur, Hardoi, Kannur, Kanpur Dehat, Kanpur Urban, } \\
\text { Kaushambhi, Lakhimpur, Lucknow, Pratapgarh, Raibarely, Sitapur, Unnao }\end{array}$ \\
\hline 3. & $\begin{array}{l}\text { North Eastern Plain } \\
\text { Zone }\end{array}$ & $\begin{array}{l}\text { Baharich, Balrampur, Basti, Deoria, Gonda, Kaushinagar, Mahamayanagar, Maharajganj, } \\
\text { Sant Kabir Nagar, Sidarthnagar }\end{array}$ \\
\hline 4. & Vindhyan Zone & Allahabad, Mirzapur, Sonebhadra \\
\hline 5. & Eastern Plain Zone & $\begin{array}{l}\text { Ambedharnagar, Azamgarh, Ballia, Barabanki, Chandauli , Faizabad, Gazipur, } \\
\text { Gorakhpur, Jaunpur, Kashiram Nagar, Maau, Sant Ravidas Nagar, Sultanpur, Varanasi }\end{array}$ \\
\hline 6. & $\begin{array}{l}\text { Mid Western Plain } \\
\text { Zone }\end{array}$ & Barelley, Bijnour, Badaun, Jyotibaphule Nagar, Rampur \\
\hline 7. & $\begin{array}{l}\text { South Western } \\
\text { Plain Zone }\end{array}$ & Agra, Aligarh, Etah, Firozabad, Hathras, Mainpur, Mathura \\
\hline 8. & $\begin{array}{l}\text { Bhabhari \& Tarai } \\
\text { Zone }\end{array}$ & Saharanpur, Pilibhit, Bijnour, Sarbatinagar \\
\hline 9. & Western Plain Zone & Bagpat, Bulandsahar, Gutam Budhnagar, Ghaziabad, Meerut, Muzaffarnagar \\
\hline
\end{tabular}

Table-2: Irrigation scheduling of wheat crop

\begin{tabular}{|l|l|l|}
\hline Irrigation & Stage & Duration \\
\hline $\mathrm{I}_{1}$ & CRI Stage $(50 \mathrm{~mm})$ & CRI $=21$ days, \\
\hline $\mathrm{I}_{2}$ & CRI + Booting $(50 \mathrm{~mm})$ & CRI $=21$ days, + Tillering $=45$ days, \\
\hline $\mathrm{I}_{3}$ & CRI + Tillering + Booting $(50 \mathrm{~mm})$ & CRI $=21$ days, + Tillering $=45$ days, + Booting $=75$ days \\
\hline $\mathrm{I}_{4}$ & $\begin{array}{l}\text { CRI }+ \text { Tillering }+ \text { Booting }+ \text { Milking } \\
(50 \mathrm{~mm})\end{array}$ & $\begin{array}{l}\mathrm{CRI}=21 \text { days, }+ \text { Tillering }=45 \text { days, }+ \text { Booting }=75 \text { days }+ \\
\text { Flowering }=85 \text { days }\end{array}$ \\
\hline $\mathrm{I}_{5}$ & $\begin{array}{l}\text { CRI }+ \text { Tillering }+ \text { Jointing }+ \\
\text { Flowering }+ \text { Milking }(50 \mathrm{~mm})\end{array}$ & $\begin{array}{l}\text { CRI }=21 \text { days, }+ \text { Tillering }=45 \text { days },+ \text { Booting }=75 \text { days }+ \\
\text { Flowering }=85 \text { days }+ \text { Milking }=100 \text { days }\end{array}$ \\
\hline
\end{tabular}

Table-3: Yield ( $\mathrm{Kg} \mathrm{ha}^{-1}$ ) using DSSAT model of different sowing dates with different irrigation of different Agroclimatic zones, Uttar Pradesh

\begin{tabular}{|l|l|l|l|l|l|l|l|l|}
\hline & \multicolumn{7}{|l|}{ Bundelkhand Agroclimatic zones Yield $\left(\mathrm{kg} \mathrm{ha}^{-1}\right)$} \\
\hline Date & OBS & Normal & IRRIG1 & IRRIG2 & IRRIG3 & IRRIG4 & IRRIG5 & Mean \\
\hline 30-Oct & 2073.9 & 2915.0 & 2418.3 & 3398.4 & 3404.5 & 3389.9 & 3383.3 & 3151.6 \\
\hline 6-Nov & 2073.9 & 3745.6 & 2598.4 & 4040.2 & 4103.2 & 4104.6 & 4104.6 & 3782.8 \\
\hline 13-Nov & 2073.9 & 4160.9 & 2485.9 & 4279.2 & 4399.5 & 4401.4 & 4401.4 & 4021.4 \\
\hline 22-Nov & 2073.9 & 4224.0 & 2229.3 & 4077.0 & 4383.5 & 4397.2 & 4397.2 & 3951.4 \\
\hline 27-Nov & 2073.9 & 4187.9 & 2176.8 & 3953.7 & 4311.7 & 4325.3 & 4325.3 & 3880.1 \\
\hline 5-Dec & 2073.9 & 4062.6 & 2153.9 & 3796.7 & 4217.1 & 4234.7 & 4234.5 & 3783.2 \\
\hline Mean & 2073.9 & 3882.68 & 2343.8 & 3924.2 & 4136.6 & 4142.2 & 4141.1 & 3761.7 \\
\hline SD & & 504.9 & 183.1 & 302.1 & 375.3 & 385.1 & 387.7 & 313.2 \\
\hline CV & & 13.0 & 7.8 & 7.7 & 9.1 & 9.3 & 9.4 & 8.3 \\
\hline RMSE & 1687.9 & & & & & & & \\
\hline
\end{tabular}

\begin{tabular}{|l|l|l|l|l|l|l|l|l|}
\hline \multicolumn{7}{|c|}{ Central Plain Zone Yield $\left(\mathrm{kg} \mathrm{ha}^{-1}\right)$} \\
\hline Date & OBS & Normal & IRRIG1 & IRRIG2 & IRRIG3 & IRRIG4 & IRRIG5 & Mean \\
\hline 30-Oct & 2912.4 & 3123.3 & 2230.4 & 3505.6 & 3529.1 & 3523.9 & 3529.2 & 3240.3 \\
\hline 6-Nov & 2912.4 & 3844.0 & 2340.1 & 3878.4 & 4068.2 & 4081.5 & 4082.1 & 3715.7 \\
\hline 13-Nov & 2912.4 & 4036.8 & 2330.9 & 3858.0 & 4182.3 & 4192.0 & 4192.3 & 3798.7 \\
\hline 22-Nov & 2912.4 & 4051.0 & 2236.8 & 3509.2 & 4087.8 & 4129.1 & 4129.1 & 3690.5 \\
\hline 27-Nov & 2912.4 & 4012.7 & 2223.4 & 3409.9 & 4069.5 & 4108.9 & 4108.4 & 3655.5 \\
\hline 5-Dec & 2912.4 & 3879.3 & 2151.4 & 3266.4 & 3941.5 & 3986.8 & 3986.3 & 3535.3 \\
\hline Mean & 2912.4 & 3824.51 & 2252.17 & 3571.2 & 3979.74 & 4003.69 & 4004.58 & 3606.0 \\
\hline SD & & 354.1 & 71.6 & 246.4 & 233.7 & 244.4 & 242.4 & 198.8 \\
\hline CV & & 9.3 & 3.2 & 6.9 & 5.9 & 6.1 & 6.1 & 5.5 \\
\hline RMSE & 693.6 & & & & & & & \\
\hline
\end{tabular}


A. K. Baxla et al; Saudi J Bus Manag Stud, May, 2020; 5(5): 284-292

\begin{tabular}{|l|l|l|l|l|l|l|l|l|}
\hline & \multicolumn{10}{|l|}{ Eastern Plain Zone Yield $\left(\mathrm{kg} \mathrm{ha}^{-1}\right)$} \\
\hline Date & OBS & Normal & IRRIG1 & IRRIG2 & IRRIG3 & IRRIG4 & IRRIG5 & Mean \\
\hline 30-Oct & 2641.6 & 2814.9 & 2145.9 & 3179.7 & 3225.3 & 3225.3 & 3225.3 & 2969.4 \\
\hline 6-Nov & 2641.6 & 3561.9 & 2285.1 & 3658.3 & 3878.1 & 3880.4 & 3881.6 & 3524.2 \\
\hline 13-Nov & 2641.6 & 3823.3 & 2263.7 & 3771.1 & 4061.4 & 4074.0 & 4073.9 & 3677.9 \\
\hline 22-Nov & 2641.6 & 3878.3 & 2171.1 & 3545.2 & 4014.2 & 4037.1 & 4037.1 & 3613.8 \\
\hline 27-Nov & 2641.6 & 3865.3 & 2179.1 & 3450.5 & 3987.0 & 4009.2 & 4010.1 & 3583.5 \\
\hline 5-Dec & 2641.6 & 3701.2 & 2118.8 & 3307.7 & 3874.3 & 3903.4 & 3903.4 & 3468.1 \\
\hline Mean & 2641.6 & 3607.5 & 2193.9 & 3485.41 & 3840.06 & 3854.9 & 3855.24 & 3472.8 \\
\hline SD & & 406.3 & 66.1 & 219.7 & 310.3 & 317.6 & 317.7 & 257.0 \\
\hline CV & & 11.3 & 3.0 & 6.3 & 8.1 & 8.2 & 8.2 & 7.4 \\
\hline RMSE & 831.3 & & & & & & & \\
\hline
\end{tabular}

\begin{tabular}{|l|l|l|l|l|l|l|l|l|}
\hline & \multicolumn{7}{|l|}{ Mid Western Zone Yield $\left(\mathrm{kg} \mathrm{ha}^{-1}\right)$} \\
\hline Date & OBS & Normal & IRRIG1 & IRRIG2 & IRRIG3 & IRRIG4 & IRRIG5 & Mean \\
\hline 30-Oct & 3034.3 & 3577.9 & 2188.7 & 3612.0 & 3791.3 & 3794.6 & 3755.8 & 3453.4 \\
\hline 06-Nov & 3034.3 & 3960.9 & 2328.9 & 3742.5 & 4132.8 & 4146.3 & 4133.6 & 3740.8 \\
\hline 13-Nov & 3034.3 & 3974.8 & 2390.4 & 3534.8 & 4083.7 & 4135.4 & 4138.8 & 3709.7 \\
\hline 22-Nov & 3034.3 & 3930.3 & 2439.0 & 3327.5 & 3966.2 & 4035.6 & 4037.7 & 3622.7 \\
\hline 27-Nov & 3034.3 & 3850.6 & 2438.3 & 3292.3 & 3896.2 & 3967.9 & 3967.9 & 3568.9 \\
\hline 05-Dec & 3034.3 & 3607.6 & 2417.5 & 3192.9 & 3735.1 & 3791.8 & 3791.8 & 3422.8 \\
\hline Mean & 3034 & 3817 & 2367 & 3450 & 3934 & 3979 & 3971 & 3586 \\
\hline SD & & 179.2 & 96.5 & 212.1 & 157.7 & 158.0 & 165.8 & 130.5 \\
\hline CV & & 4.7 & 4.1 & 6.1 & 4.0 & 4.0 & 4.2 & 3.6 \\
\hline RMSE & 564.8 & & & & & & & \\
\hline
\end{tabular}

\begin{tabular}{|l|l|l|l|l|l|l|l|l|}
\hline & \multicolumn{7}{|c|}{ North Eastern Plain Zone Yield $\left(\mathrm{kg} \mathrm{ha}^{-1}\right)$} \\
\hline Date & OBS & Normal & IRRIG1 & IRRIG2 & IRRIG3 & IRRIG4 & IRRIG5 & Mean \\
\hline 30-Oct & 2591.4 & 2685.8 & 2030.3 & 3045.8 & 3064.0 & 3065.2 & 3064.4 & 2825.9 \\
\hline 6-Nov & 2591.4 & 3443.0 & 2192.3 & 3530.8 & 3682.3 & 3686.7 & 3687.0 & 3370.4 \\
\hline 13-Nov & 2591.4 & 3699.2 & 2230.0 & 3667.6 & 3878.3 & 3884.2 & 3884.3 & 3540.6 \\
\hline 22-Nov & 2591.4 & 3764.9 & 2213.9 & 3434.8 & 3868.7 & 3869.2 & 3869.4 & 3503.5 \\
\hline 27-Nov & 2591.4 & 3745.0 & 2217.0 & 3299.8 & 3836.4 & 3854.6 & 3850.1 & 3467.2 \\
\hline 5-Dec & 2591.4 & 3628.8 & 2100.7 & 3068.5 & 3715.2 & 3737.4 & 3737.4 & 3331.4 \\
\hline Mean & 2591.4 & 3494.4 & 2164 & 3341.2 & 3674.2 & 3682.9 & 3682.1 & 3339.8 \\
\hline SD & & 412.9 & 80.4 & 250.8 & 309.8 & 312.8 & 312.7 & 264.0 \\
\hline CV & & 11.8 & 3.7 & 7.5 & 8.4 & 8.5 & 8.5 & 7.9 \\
\hline RMSE & 748.4 & & & & & & & \\
\hline
\end{tabular}

\begin{tabular}{|l|l|l|l|l|l|l|l|l|}
\hline & \multicolumn{7}{|l|}{ Western Plain Zone Yield $\left(\mathrm{kg} \mathrm{ha}^{-1}\right.$ ) } \\
\hline Date & OBS & Normal & IRRIG1 & IRRIG2 & IRRIG3 & IRRIG4 & IRRIG5 & Mean \\
\hline 30-Oct & 3648.2 & 2549.2 & 1938.1 & 2850.5 & 2860.6 & 2872.2 & 2863.6 & 2655.7 \\
\hline 06-Nov & 3648.2 & 3306.3 & 2126.4 & 3445.3 & 3539.9 & 3527.3 & 3527.3 & 3245.4 \\
\hline 13-Nov & 3648.2 & 3546.0 & 2135.4 & 3524.7 & 3716.4 & 3719.2 & 3719.2 & 3393.5 \\
\hline 22-Nov & 3648.2 & 3497.8 & 2155.4 & 3216.8 & 3571.6 & 3587.6 & 3587.6 & 3269.5 \\
\hline 27-Nov & 3648.2 & 3434.7 & 2254.7 & 3184.7 & 3562.7 & 3563.2 & 3563.2 & 3260.5 \\
\hline 05-Dec & 3648.2 & 3256.4 & 2123.1 & 3005.4 & 3396.3 & 3388.7 & 3388.7 & 3093.1 \\
\hline Mean & 3648 & 3265 & 2122 & 3205 & 3441 & 3443 & 3442 & 3153 \\
\hline SD & & 367.7 & 102.7 & 255.3 & 302.1 & 299.2 & 302.5 & 261.7 \\
\hline CV & & 11.3 & 4.8 & 8.0 & 8.8 & 8.7 & 8.8 & 8.3 \\
\hline RMSE & 549.9 & & & & & & & \\
\hline
\end{tabular}


A. K. Baxla et al; Saudi J Bus Manag Stud, May, 2020; 5(5): 284-292

\begin{tabular}{|l|l|l|l|l|l|l|l|l|}
\hline & \multicolumn{10}{|c|}{ South Western Arid Zone Yield $\left(\mathrm{kg} \mathrm{h}^{-1}\right)$} \\
\hline Date & OBS & Normal & IRRIG1 & IRRIG2 & IRRIG3 & IRRIG4 & IRRIG5 & Mean \\
\hline 30-Oct & 3190.7 & 3517.3 & 2127.6 & 3704.4 & 3844.4 & 3851.1 & 3851.1 & 3482.7 \\
\hline 6-Nov & 3190.7 & 4169.6 & 2193.6 & 3995.5 & 4333.7 & 4362.3 & 4347.0 & 3900.3 \\
\hline 13-Nov & 3190.7 & 4272.0 & 2131.6 & 3797.4 & 4370.9 & 4413.9 & 4417.2 & 3900.5 \\
\hline 22-Nov & 3190.7 & 4206.1 & 2075.3 & 3454.9 & 4215.5 & 4263.0 & 4272.3 & 3747.8 \\
\hline 27-Nov & 3190.7 & 4147.8 & 2046.3 & 3372.7 & 4177.8 & 4251.9 & 4251.1 & 3708.0 \\
\hline 5-Dec & 3190.7 & 3909.5 & 1993.1 & 3255.6 & 3952.5 & 4031.9 & 4031.8 & 3529.1 \\
\hline Mean & 3190.7 & 4037.1 & 2094.6 & 3596.7 & 4149.1 & 4195.7 & 4195.1 & 3711.4 \\
\hline SD & & 282.8 & 71.1 & 282.0 & 209.8 & 213.8 & 212.8 & 178.0 \\
\hline CV & & 7.0 & 3.4 & 7.8 & 5.1 & 5.1 & 5.1 & 4.8 \\
\hline RMSE & 520.7 & & & & & & & \\
\hline
\end{tabular}

\begin{tabular}{|l|l|l|l|l|l|l|l|l|l|}
\hline & \multicolumn{7}{|c|}{ Vindhyan Zone Yield $\left(\mathrm{kg} \mathrm{ha}^{-1}\right)$} \\
\hline Date & OBS & Normal & IRRIG1 & IRRIG2 & IRRIG3 & IRRIG4 & IRRIG5 & Mean \\
\hline 30-Oct & 1890.2 & 2524.1 & 2105.5 & 3025.8 & 3025.8 & 3025.8 & 3025.8 & 2788.8 \\
\hline 6-Nov & 1890.2 & 3315.1 & 2286.5 & 3590.5 & 3673.1 & 3679.8 & 3679.8 & 3370.8 \\
\hline 13-Nov & 1890.2 & 3723.2 & 2279.8 & 3854.7 & 3975.2 & 3976.5 & 3976.5 & 3631.0 \\
\hline 22-Nov & 1890.2 & 3812.2 & 2142.8 & 3671.3 & 3970.8 & 3973.3 & 3973.3 & 3590.6 \\
\hline 27-Nov & 1890.2 & 3802.4 & 2124.5 & 3563.1 & 3931.0 & 3933.0 & 3933.9 & 3548.0 \\
\hline 5-Dec & 1890.2 & 3712.9 & 2136.2 & 3422.2 & 3900.8 & 3902.2 & 3902.2 & 3496.1 \\
\hline Mean & 1890.2 & 3481.7 & 2179.2 & 3521.3 & 3746.1 & 3748.4 & 3748.6 & 3404.2 \\
\hline SD & & 503.7 & 81.5 & 281.3 & 370.2 & 370.7 & 370.8 & 314.7 \\
\hline CV & & 14.5 & 3.7 & 8.0 & 9.9 & 9.9 & 9.9 & 9.2 \\
\hline RMSE & 1514.0 & & & & & & & \\
\hline
\end{tabular}

\begin{tabular}{|l|l|l|l|l|l|l|l|l|}
\hline & \multicolumn{7}{|c|}{ Bhabhara \& Tarai Zone Yield (kg ha $\left.{ }^{-1}\right)$} \\
\hline Date & OBS & Normal & IRRIG1 & IRRIG2 & IRRIG3 & IRRIG4 & IRRIG5 & Mean \\
\hline 30-Oct & 2927.6 & 3983.8 & 2559.8 & 3929.4 & 4153.0 & 4156.5 & 4103.3 & 3814.3 \\
\hline 06-Nov & 2927.6 & 4165.7 & 2662.5 & 3957.4 & 4314.6 & 4324.6 & 4322.6 & 3957.9 \\
\hline 13-Nov & 2927.6 & 4171.0 & 2804.8 & 3803.3 & 4309.0 & 4331.8 & 4331.2 & 3958.5 \\
\hline 22-Nov & 2927.6 & 4041.9 & 2844.3 & 3603.2 & 4109.8 & 4144.4 & 4148.5 & 3815.3 \\
\hline 27-Nov & 2927.6 & 3912.0 & 2876.7 & 3576.8 & 3983.2 & 4072.0 & 4076.5 & 3749.5 \\
\hline 05-Dec & 2927.6 & 3690.5 & 2799.6 & 3432.9 & 3844.6 & 3860.6 & 3861.4 & 3581.6 \\
\hline Mean & 2928 & 3994 & 2758 & 3717 & 4119 & 4148 & 4141 & 3813 \\
\hline SD & & 180.0 & 121.6 & 211.5 & 184.0 & 175.2 & 174.9 & 141.2 \\
\hline CV & & 4.5 & 4.4 & 5.7 & 4.5 & 4.2 & 4.2 & 3.7 \\
\hline RMSE & 894.6 & & & & & & & \\
\hline
\end{tabular}

\section{CONCLUSION}

The model was run for 6 sowing dates starting on 30 October and repeated every 7 days until 5 December using long-term district level station and gridded level historical weather data from different district. Results showed that optimum sowing date (13th Nov.) was found better as compared to early (30 October) and late (5 December) sowings. The model performance was found good and satisfactory having 34 irrigations $\left(\mathrm{I}_{3}\right.$ and $\left.\mathrm{I}_{4}\right)$. On an average, the performance of model for $\mathrm{I}_{4}$ was found good. This showed that model worked better under optimum sowing with optimum irrigation. The error per cent by CERESwheat model showed that in majority of the cases the models had underestimated wheat yield. The results showed that the model worked better under optimum sowing with optimum irrigation as compared to early/late sowing and moisture stress conditions. Optimum sowing window was different among districts.
Simulation results depicts that 22 November is the optimum sowing date for Bundelkhand, Central Plain zone, Eastern plain zone, NE Plain zone and Vindhyan zone and 13 November for Mid western plain zone, SW plain zone, Bhabhara \& Tarai zone and Western plain zone.

\section{LIMITATIONS}

The model does not include the other nutrient factors, i.e. phosphorus, potassium and plant essential micronutrients. These nutrients and micronutrients are assumed to be in abundant supply in the soil so as not to cause any stress on the crop, which is often not true. Similarly, losses due to weeds, pests and diseases are also not included in the model. Due to favourable weather conditions, pest infestation and diseases may cause losses to the crops, which cannot be simulated at present using the model. 


\section{REFERENCES}

1. Singh, K. K., Baxla, A. K., Mall, R. K., Singh, P. K., Balasubramanyam, R., \& Garg, S. (2010). Wheat yield prediction using CERES-Wheat model for decision support in agro-advisory. Vayu mandal, 5, 97.

2. Singh, K., Sharma, S. N., \& Sharma, Y. (2011). Effect of high temperature on yield attributing traits in Bread Wheat. Bangladesh Journal of Agricultural Research, 36(3):415-426 (Rodenwaltdt and Jusatz, H.eds.), Spring Verlag, Berlin.

3. Shantha, N. (2002). Physiological traits associated with yield performance of spring wheat (triticum aestivum) under late -sown conditions. Indian Journal of Agricultural Sciences, 72 (3):135-140.

4. Alderfasi, A. A., \& Nielsen, D. C. (2001). Use of crop water stress index for monitoring water. Agric Water Manage, 47:69-75.

5. Attri, S. D., Singh, K. K., \& Mall, R. K. (2012). Simulation of growth and yield attributes of wheat genotype under changing climate in recent years in India. 16:221-234.

6. Nain, A. S., Dadhwal, V. K., \& Singh, T. P. (2004). Use of CERES-Wheat model for wheat yiled forecast in central Indo-Gangetic plains of India. Journal Agricultural Science (camb), 142:59-70.

7. Mall, R. K., \& Aggarwal, P. K. (2002). Climate change and rice yields in diverse agroenvironments of India. I. Evaluation of impact assessment models. Climate change, 52(3):315331.

8. Saxena, R., Bhardwaj, V., \& Kalra, N. (2006). Simulation wheat yield using WTGROWS in northern India. Journal of Agrometeorology, 8(1): 87-90

9. Mall, R. K., Singh, R., Gupta, A., Srinivasan, G., \& Rathore, L. S. (2006). Impact of climate change on Indian agriculture: a review. Climate Change, 78:445-478.

10. Angstrom, A. (1924). Solar and terrestrial radiation. $Q J$ Roy Meteorol Soc, 50:121-126.

11. Richardson, C. W. (1981). Stochastic simulation of daily precipitation, temperature, and solar radiation. Water Resour Res, 17(1):182-190.

12. Richardson, C. W. (1985). Weather simulation for crop management models. Trans. ASAE, 28(5), 1602-1606. 